\title{
An exploration of stereotype perceptions amongst support staff within a South African higher education institution
}

\author{
Authors: \\ Given R.B. Moloto \\ Lizelle Brink ${ }^{1}$ \\ J. Alewyn $\mathrm{Nel}^{1}$

\begin{abstract}
Affiliations: Sciences, North-West University, Potchefstroom Campus, South Africa
\end{abstract} \\ ${ }^{1}$ Workwell Research Unit for \\ Economic and Management

\section{Correspondence to:} \\ Lizelle Brink \\ Email: \\ lizelle.brink@nwu.ac.za

\section{Postal address:} \\ Private Bag X6001, \\ North-West University, \\ Potchefstroom 2520, \\ South Africa \\ Dates: \\ Received: 18 July 2013 \\ Accepted: 19 Nov. 2013 \\ Published: 25 Feb. 2014 \\ How to cite this article: \\ Moloto, G.R.B., Brink, \\ L., \& Nel, J.A. (2014). An \\ exploration of stereotype \\ perceptions amongst \\ support staff within a \\ South African higher \\ education institution. SA \\ Journal of Human Resource \\ Management/SA Tydskrif vir \\ Menslikehulpbronbestuur, \\ 12(1) Art. \#573, 12 pages. \\ http://dx.doi.org10.4102/ \\ sajhrm.v12i1.573

\section{Copyright:} \\ (c) 2014. The Authors. \\ Licensee: AOSIS \\ OpenJournals. This work \\ is licensed under the \\ Creative Commons \\ Attribution License.
}

Read online:

Scan this QR code with your smart phone or mobile device to read online.
Orientation: After the 1994 democratic elections, South African organisations had to replace discriminatory policies with new policies to integrate all people and to embrace diversity. As a consequence stereotypes may be more prevalent in diverse working environments.

Research purpose: The objective of this study was to explore the experience of stereotypes amongst the support staff within a higher education institution.

Motivation for this study: Changes within South African working environments, and specifically higher education institutions, resulted in more diverse management teams and a more culturally diverse workforce. With this in mind, the experience of stereotypes may become more prevalent within South African working environments. Many researchers have focused on stereotypes; however, studies on stereotypes within South Africa are limited, especially within higher education institutions.

Research approach, design and method: The research approach was qualitative and a case study design was employed. A combination of both quota and convenience sampling was used. The sample consisted of $(N=30)$ support staff within a higher education institution in South Africa. Semi-structured interviews were used to collect data.

Main findings: The results indicated that the participants do experience stereotypes within their workplace and also hold stereotypes of other people within their workplace. The most prevalent stereotypes mentioned by participants were age, gender, racial and occupational stereotypes. There is also an indication that stereotypes have cognitive, emotional and behavioural effects on the stereotyped.

Practical/managerial implications: Organisations should do away with stereotyping by embracing and managing diversity and dealing with stereotypes, specifically within higher education institutions. When managers are aware of stereotypes and the effects thereof in the organisation, they can make every effort to eradicate the stereotypes and address the impact thereof.

Contribution: In an environment where there is a diverse workforce, stereotyping is more likely to exist. This study will provide useful information about stereotypes within a higher education institution seeing that there are a limited number of studies on this topic within South Africa and within this specific occupation. The results of the study will enlighten the organisation to become more aware of stereotypes and the debilitating impact that they have on the individual and the organisation, thereby providing the organisation with the opportunity to address stereotypes and the impact thereof on employees and the organisation.

\section{Introduction}

\section{Problem statement Background}

According to Mayekiso and Snodgrass (2008), the political, economic, social and technological landscape in post-apartheid South Africa is demanding and challenging. This is because South Africa is undergoing a process of transformation since the first democratic elections in 1994. Institutions and organisations are fundamentally changed as individuals come into contact with people who think, look and live differently. In addition to the many and varied structural changes occurring in South African institutions of higher education, academic leaders face increasing diversity issues. These issues relate to race, age, gender, marital status, sexual orientation and so forth because of a changing and diverse workforce (Mayekiso \& Snodgrass, 2008). De Klerk and Radloff (2010) mention that the challenge facing universities is to respond quickly to the national imperative to facilitate transformation, both in terms of day-to-day institutional practices as well as perceptions, attitudes and mindsets. Although very elusive and invisible, these are the most powerful determinants of the prospects for success in any efforts to achieve real change. 
According to Bowen, Kurzweil and Tobin (2005), higher education institutions have become the gatekeepers to full social, economic and political citizenship. Yet, they remain a long way from reaching the goal of becoming genuinely inclusive, diverse and democratic. Norris (1996) states that although most higher education institutions have changed their admission and recruitment policies, they still do not reflect the demographics of South African society. Niemann (2006) states that the education sector in South Africa has to be prepared to facilitate diversity to ensure the effective functioning of its institutions. The problem is that managers have to know how to plan for and handle such issues.

According to Gordon (2001), a diverse workforce also includes people with varying attitudes. People have an array of beliefs, formed in large part from their socio-economic and cultural backgrounds and other experiences and these varying beliefs likely result in different attitudes. Niemann (2006) mentions that management teams and employees have to change their attitudes regarding a range of issues, from racial and gender attitudes to attitudes about the disabled. This has to be done in order to comply with South African legislation, and to adjust and effectively manage the different contexts in which institutions or organisations are presently operating. One of the biggest obstacles in dealing with such a diverse workforce is breaking through people's conceived attitudes about those who are different from themselves (McKinney, 1996). All of these differences can lead to stereotyping, which may result in workplace tension (Solovic, 2010). Buelens, Sinding, Waldstrøm, Kreitner and Kinicki (2011) agree with this by stating that diversity contributes to stereotypes forming in the organisation, which causes conflict and in turn influences the organisational climate. Roberson and Kulik (2007) suggest that managers should converse with their employees about stereotypes; one manner in which this can be achieved is diversity training that specifically equips managers with the necessary skills and confidence to do so.

\section{Literature review}

Kassin, Fein and Markus (2011) define a stereotype as a belief or association that links a whole group of people with certain traits or characteristics. Stereotyping refers to a set of assumptions held about an individual or situation based on previous experience or societal norms (Sargeant, 2011). According to Rake and Lewis (2009), once a stereotype is applied to an individual, it is assumed that they will behave in a certain way, in line with a fixed general idea or set of associated images. Hinton (2000) states that people use stereotypes, often unconsciously in an unfamiliar situation, in first meetings, which could be one of the reasons why people categorise. Schneider (2004) states that stereotypes often seem to be integrally related to the group memberships and to conflict between groups. He further states that people seem to have stronger and more negative stereotypes about groups to which they do not belong (i.e. out-group) than to those to which they do (in-group).

Kreitner and Kinicki (2004) and Kassin et al. (2011) state that stereotypes are not always negative and inaccurate; some are more accurate than others. Although many stereotypes are based on completely illusory information or perceptions, some do stem from a kernel of truth, and still others may be fairly accurate (Kassin et al., 2011). Burgess (2003) also states that stereotypes are only a problem when they are inaccurate, especially when those inaccuracies are negative and hostile. Sanderson (2010) states that although stereotypes may sometimes be relatively harmless, they can also lead to prejudice, which means hostile or negative feelings about people based on their group membership. According to Brotherton (2007), stereotypes can be both causes and consequences of prejudice. Stereotypes underlie all prejudice, and pervade acts of violence, segregation and discrimination against minority groups (Moore, 2006). Dovidio, Glick and Rudman (2005) point out that the stereotype acts as both a justificatory device for categorical acceptance or rejection of a group, and as a screening or selective device to maintain simplicity in perception in thinking.

\section{Types of stereotypes}

There are different types of stereotypes found in literature (Falkenberg, 1990; Larkin, 2008; Plous, 2003). This study focused mainly on the four common types of stereotypes: age, gender, racial and occupational stereotypes. These types of stereotypes appear to exist in many working environments.

Age stereotypes: Sargeant (2011) states that age stereotyping is concerned with associating certain characteristics, or lack of them, with certain ages. Robinson, Gustafson and Popovich (2008) mention that age stereotypes homogenise the particular age group as being all the same rather than recognising any diversity within that age group. Age stereotypes reinforce age discrimination because of their negative orientation (Kreitner \& Kinicki, 2004). This type of stereotype is not restricted to older people; it can apply to all ages and age groups (Sargeant, 2011). Long-standing age stereotypes depict older workers as less satisfied, not as involved with their work, less motivated and less productive than the young workers (Kreitner \& Kinicki, 2004). Younger workers are perceived to be more dynamic, enthusiastic and more friendly with regard to information technology (Sargeant, 2011). According to Kreiter and Kinicki (2004), these stereotypes are based more on fiction than fact. Gordon (2001) argues that the myths about older workers' inability to learn, slow speed of response and inflexibility are not true because older workers can demonstrate the same creativity, adaptability and manageability as younger workers.

Gender stereotypes: Kreitner and Kinicki (2004) define gender stereotypes as beliefs that differing traits and abilities make men and women well suited to different roles. Gender stereotypes tend to be prescriptive as well as descriptive (Fiske \& Stevens, 1993). Madden (2011) states that gender stereotypes are pervasive and have an impact on all aspects of women's and men's behaviour. Prime, Jonsen, Carter and Maznevski (2008) suggest that men's stereotypes have the 
potential to undermine women, even when the stereotypes may be seen as positive. Research by Eagly and Karau (2002) finds that women are perceived as modestly more effective in education, government and social services than in other kinds of organisations. Women are perceived to be more submissive, emotional, affectionate, talkative, patient and creative than men. Men, on the other hand, are perceived to be more assertive, aggressive, courageous, competitive and ambitious than women (Kreitner \& Kinicki, 2004).

Racial stereotypes: According to Pauker, Ambady and Apfelbaum (2010) individuals are divided into social categories on the basis of their race. Stereotypes about racial groups have various negative consequences. According to Fiske and Taylor (1991) negative racial stereotypes may result in prejudice such that individuals are seen as unsuitable for a specific position because of their race. Powell and Butterfield (2002) add to this by stating that white men are often viewed as being better suited for high-status positions than individuals of other races. Not only do racial stereotypes influence our perceptions, but they also influence our feelings and behaviours towards races different from our own (Gordijn, Finchilescu, Brix, Wijnants \& Koomen, 2006).

Occupational stereotypes: Occupational stereotyping has been defined as a preconceived attitude about a particular occupation, about people who are employed in that occupation, and about one's own suitability for that occupation (Lipton, O'Connor, Terry \& Bellamy, 1991). Several studies have demonstrated that stereotypes of people in different jobs exist (McLean \& Kalin, 1994) and that particular traits are deemed more suitable for some jobs than for others (Arkkelin \& O'Connor, 1992). According to Larkin (2008), many jobs are still perceived as better suited to women (e.g. nurse, preschool teacher) or men (e.g. construction worker, truck driver). Oswald (2003) state that occupational titles associated with men are perceived to be more prestigious than those associated primarily with women. Examples of occupational stereotypes include 'lawyers are liars' and 'car salesmen are dishonest' (Basow, 1992).

\section{Consequences of stereotypes}

According to Singletary, Ruggs, Hebl and Davies (2009), stereotypes about an individual's group, which can be shaped as either positive or negative, elicit a variety of emotions. Negative stereotypes often cause negative responses which can manifest themselves in the stereotyped individual's reactions, performance on a task, motivation and self-esteem (Singletary et al., 2009). Research has shown that the threat of being evaluated, judged by or treated in terms of a negative stereotype can cause individuals to perform worse in a domain in which negative stereotypes exist about a group of which they are a member. Spencer, Steele and Quinn (1999) and Steele and Aronson (1995) term this phenomenon as stereotype threat.

Stereotype threat exerts its effects through multiple processes (Schmader, Johns \& Forbes, 2008). One of these is the triggering of physiological arousal, which may interfere with people's ability to perform well at the task at hand (Ben-Zeev, Fein \& Inzlicht, 2005; Blascovich, Spencer, Quinn \& Steele, 2001; O'Brien \& Crandall, 2003). Other negative physical health effects associated with constant exposure to stereotypes are coronary heart disease and hypertension (Clark, Anderson, Clark \& Williams, 1999; Mendes, Major, McCoy \& Blaschovich, 2008). Thomas, Bardwell, AncoliIsrael and Dimsdale (2006) also report that other negative physiological effects are difficulty sleeping and constant fatigue.

Furthermore, Gill (2012) mentions that in the corporate world, there is a high price to be paid for stereotyping and that includes litigation, lost employees, poor employee morale, lost sales and customers, difficulty hiring top-level employees, difficulty retaining employees and diminished productivity or profits. Gill further mentions that people also suffer personal consequences when people judge other people based on bias, labels and stereotypes. People miss out on valuable experiences, connecting with others on a genuine level, gaining insights and forming sincere relationships.

Sanderson (2010) mentions that constant exposure to stereotypes is also associated with negative psychological effects. People who perceive discrimination due to racial stereotypes are more likely to report depression, sadness, helplessness, anxiety and substance abuse (Branscombe, Schmitt \& Harvey, 1999; Gibbons, Gerrard, Cleveland, Wills \& Brody, 2004; Schmitt \& Branscombe, 2002). Stereotype threat can also cause negative thoughts, worry and feelings of dejection, and they can cause individuals to focus more on trying to avoid failure than on achieving success (Sanderson, 2010). Schmader and Johns (2003) also state that stereotype threat impairs the threatened individual's working memory, which, of course, impairs task performance.

From the above it is quite clear that stereotypes are an important topic that warrants further research. Various stereotypes are prevalent within literature, and it is also evident that stereotypes have a definite impact on both the individual and the organisation. Seeing that South Africa is such a diverse country, it is possible that stereotypes are even more prevalent within the country. However, research in this regard is lacking in South Africa, and specifically within higher education institutions. Therefore, the objectives of this study is firstly to explore the different types of stereotypes that individuals working in a higher education experience themselves, secondly to determine how they experience these stereotypes and lastly to investigate the stereotypes these individuals hold of others within their working environment.

\section{Research design Research approach}

The research approach that is followed in the study is qualitative research from a phenomenological approach. According to Salkind (2009) this approach seeks to understand a given research problem or topic from the perspective of 
the local population it involves. It provides information about the 'human' side of an issue. The main goal of the phenomenological approach is to discover universal themes to explain the series of meanings of a phenomenon (Lester, 1999). Therefore the researchers of this study are focused on determining the description and experience of stereotypes as they experience it themselves.

\section{Research strategy}

The case study is used as a design. According to Salkind (2009) a case study is a method used to intensely study a person or an institution in a unique setting or situation. The study's unit of analysis is individual employees working in a higher education institution. Therefore several case studies were studied within a higher education institution.

\section{Research method}

\section{Research setting}

This research took place at a higher education institution within South Africa. The participants were interviewed at their offices for the sake of convenience, so that they could feel comfortable and to ensure privacy. A 'do not disturb' sign was put outside their doors to avoid disruptions. The researcher introduced herself in a welcoming and friendly manner to ensure that the participants were at ease. The researcher then clearly explained the context of the interview and, with the permission of the participant, the interview was tape recorded.

\section{Entrée and establishing researcher roles}

Permission was requested from the authorities of the higher education institution to conduct the research and to conduct interviews with the participants working at the institution. The participants were contacted, and dates and times that best suited them were scheduled. The researcher explained the purpose of the study and the context of the interview. The researcher explained to the participants what was expected of them, the amount of time likely to be required for participation, the fact that their participation was voluntary, that they could withdraw at any time with no negative repercussions and how confidentiality would be ensured. All this information was provided in a language that the participant could understand. Permission was requested from the participants to tape record the interview sessions. The participants were requested to sign a consent form after being provided with the above-mentioned information.

\section{Sampling}

For this study, a combination of both quota and convenience sampling was used. In quota sampling, the purpose is to draw a sample that has the same proportions of characteristics as the population (Bless, Higson-Smith \& Kagee, 2006). Quota sampling is often more convenient and economical and data can be collected at an arbitrary location (Bless et al., 2006). MacNealy (1999) states that convenience sampling includes participants who are readily available and agree to participate in a study.

The criteria for inclusion in this research was individuals who: (1) were support staff working in the academic environment, (2) were able to speak English, (3) differed according to age, gender and race and (4) were willing to participate in the research and prepared to have a taperecorded interview with the researcher. The sample consisted of support staff $(N=30)$ within a higher education institution in South Africa.

Over half of the participants were female (53\%). In terms of race, $53 \%$ of the sample was black, whilst $20 \%$ were white and another $20 \%$ were mixed race. Only $7 \%$ of the participants were indian. With regard to language, $27 \%$ were Afrikaans speakers, whilst $20 \%$ were English speaking and a further $20 \%$ were Setswana speakers. The majority of the sample group (93\%) had a postgraduate degree qualification; the rest had obtained further education and training.

\section{Data collection methods}

Semi-structured interviews were used to collect data. An interview schedule was developed before conducting the interviews. The interview started with an introduction and an explanation of the purpose of the research. All participants were asked the following three standard questions:

- 'Do you associate yourself with any stereotypes within your workplace?' (Do you think there are any stereotypes about yourself within your workplace?)

- 'How do you experience these stereotypes?'

- 'What stereotypes do you hold of other people in your workplace?'

A pilot study was conducted with three participants from the support and administration staff of the higher education institution in order to ensure that these questions were understood correctly by the participants. Each of the participants was requested to complete a short biographical questionnaire (gender, race, etc.) at the end of each interview.

\section{Recording of data}

During the interview, the conversation was recorded with a tape recorder then transcribed at a later stage. Participants gave consent to have tape-recorded interviews. The identities of participants remained anonymous. Transcribed interviews and tape recorders were safely and securely stored.

\section{Data analysis}

Data was coded and, thereafter, analysed by the use of content analysis. According to Kerlinger (2000) content analysis consists of the following steps:

- Step 1: Content analysis is applied to get a collective understanding of the context that must be analysed. All the answers of the participants were defined and categorised.

- Step 2: Sub-units of the analysis were determined, that is words and themes. The researcher examined all the respondents' notes to attain a clear understanding. 
Subsequently, the researcher examined the notes for the purpose of establishing themes. A continued analysis of the information was carried out until repeated themes were identified. The strong themes that were identified were explored further.

- Step 3: Data was freed from redundant information in order to establish the meaning of sub-units by linking it to the whole picture.

\section{Strategies employed to ensure quality data}

Guba's model for qualitative research (Guba, 1981; Krefting, 1991; Lincoln \& Guba, 1985; Terre Blanche \& Durrheim, 1999) was used with the aim of ensuring the trustworthiness of the findings. These included credibility, transferability, dependability and conformability.

Credibility: According to Streubert and Carpenter (1999), credibility can be established when participants distinguish the reported research findings as their own experiences. This was done by ensuring that the views of the participants and the reconstruction of these views by the researcher coincided (Schurink, Fouche \& De Vos, 2011).

Transferability: Transferability refers to the extent to which the results can be generalised to other contexts and settings (Durrheim \& Wassenaar, 2002). Transferability was achieved by richly describing the data.

Dependability: Dependability entails that the research should show the same findings when it is repeated with the same or similar participants in the same context. In order to do this, the researcher documented the research process in a logical and well-structured manner (Schurink et al., 2011).

Conformability: Regarding conformability, the researcher remained neutral throughout the study and did not manipulate the research.

\section{Reporting}

Results were reported in table format. Themes and subthemes were extracted from the interviews and direct quotations were used to confirm results. The researchers only made use of the most descriptive quotations in order to substantiate the results of this study.

\section{Findings}

The findings of this study were organised into three major categories and various themes and sub-themes. Below, categories and relevant themes and sub-themes will be discussed. The various tables show the themes and subthemes. Direct quotations are also included to support the findings.

\section{Perceived stereotypes about oneself (Category 1)}

In this category, the participants were requested to give examples of stereotypes that they associate with themselves within their workplace. It was clear that the participants do identify themselves with the stereotypes that are in existence within their workplace. However, a third of the participants indicated that they did not associate themselves with any stereotypes within their workplace.

Table 1 indicates the broad themes on the perceived stereotypes about oneself, the sub-themes, characteristics as well as the examples of original responses that were analysed. The main perceived stereotypes about oneself included age, gender, occupational, qualifications and racial. Examples of the stereotypes that the participants associate with themselves are as follows:

Age: Young employees believe that they are perceived to be incompetent by older employees. Older employees associate themselves with the stereotype that they are seen to be more mature and professional but on the other hand are seen to be inefficient by younger employees.

Gender: Men perceive themselves to be valuable. Women associate themselves with the stereotype that they are inefficient, incompetent and not intelligent. Women see themselves as having to work hard to prove themselves, be more assertive to pull rank and they feel they are disregarded as leaders, undervalued and that they are taken advantage of.

Occupational: Human Resources personnel perceive themselves to be undermined by other employees. Human Resources specialists associate themselves with the stereotype that they are conceited and knowledgeable. Negotiators believe they are perceived to be untrustworthy. Support staff have a perception that they are seen to be not intelligent. Subordinates perceive themselves to be disregarded by managers.

Racial: Black people perceive themselves to be stereotyped as being disrespectful, not intelligent, not hardworking, not knowledgeable, incompetent and involved in criminal activities. Mixed race people associate themselves with the stereotypes that they are gangsters, drink a lot and are wild and incompetent. Indian people are of the opinion that they are viewed as being crooks and materialistic. White people believe that they are stereotyped to be conceited, knowledgeable and racist. Expatriates identify themselves with the stereotype that there are limited employment opportunities for them.

The most reported perceived stereotype about oneself is the racial stereotype whilst stereotypes about expatriates are the least reported. Most of the participants seemed to have negative perceptions about themselves across the different groupings within their workplace. The only group that seemed to have a positive perception about themselves were male participants.

\section{The experience of stereotypes (Category 2)}

The participants were requested to give an account of 
TABLE 1: Perceived stereotypes about oneself.

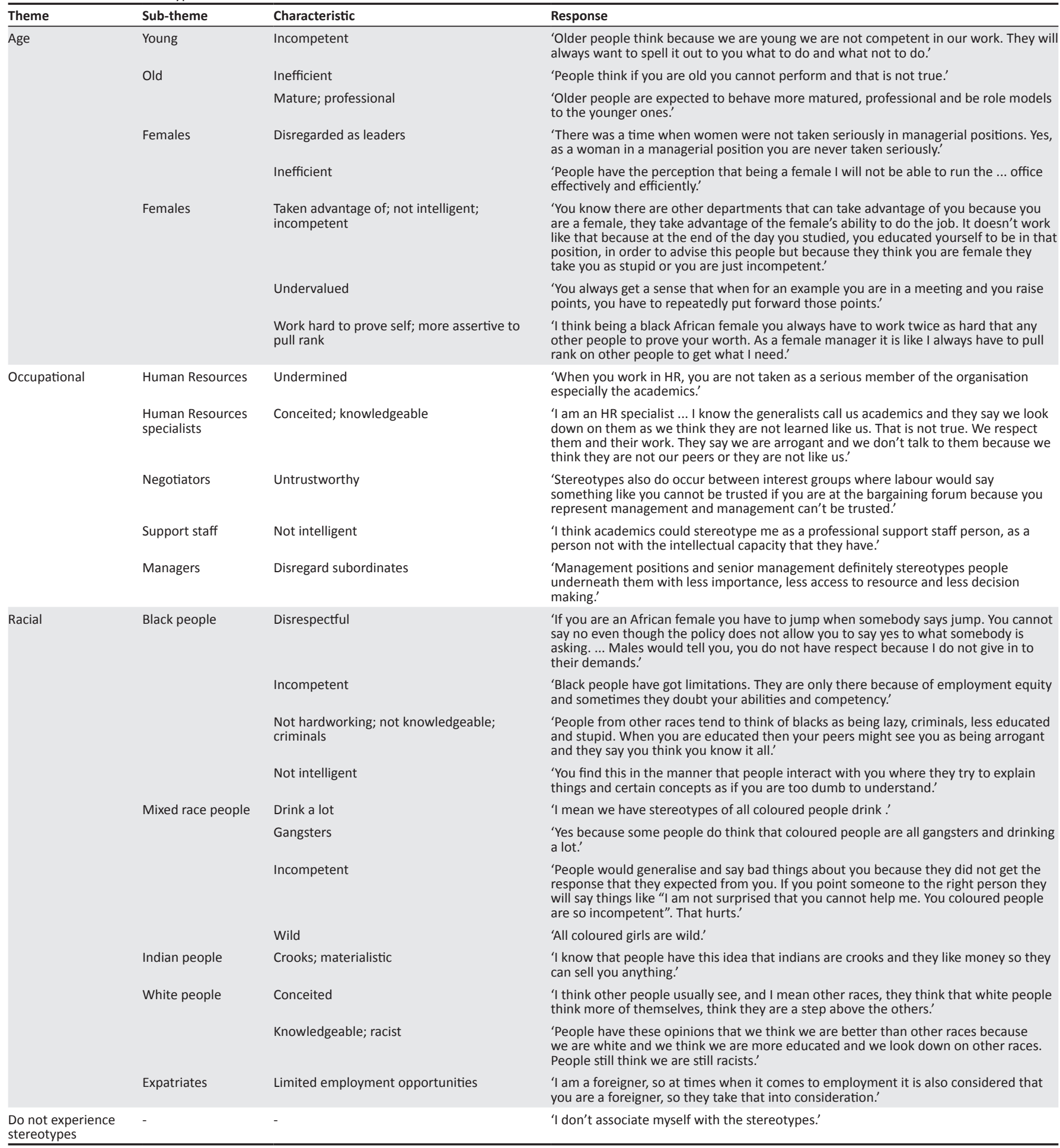

stereotypes

$(N=30)$

the stereotypes they were confronted with and how they experience them. Whilst many participants gave account of their experiences, a number of participants reported that they were not bothered by the stereotypes and that the stereotypes had no effect on them.

Table 2 indicates the broad themes on the experience of stereotypes, the sub-themes and the examples of original responses that were analysed. Stereotypes can have different effects on different people. Kreitner and Kinicki (2004) provide an explanation of different effects as follows: emotional effect includes the feelings or emotions one has about an object or situation. Cognitive effect is the belief or ideas one has about an object or situation. Behavioural effect is how one intends to act or behave towards someone or something. The broad themes that were identified include:

Behavioural effect: The participants reported that when they are confronted with stereotypes they respond by either, avoiding the person who holds the stereotype, becoming 
TABLE 2: Experience of stereotypes.

\begin{tabular}{|c|c|c|}
\hline Theme & Sub-theme & Response \\
\hline \multirow[t]{4}{*}{ Behavioural effect } & Avoiding & $\begin{array}{l}\text { 'I think because I have dealt with so many people one learned how to deal with people in general. If somebody is saying } \\
\text { something bad it doesn't help to confront the person, you just avoid that person.' }\end{array}$ \\
\hline & Defensive & $\begin{array}{l}\text { 'You are always on guard. You are just waiting for somebody to say something. You are always on guard. Every time they want } \\
\text { to talk to you about something you are always on a defensive mode already trying to think ahead.' }\end{array}$ \\
\hline & Prove yourself & $\begin{array}{l}\text { 'Irritates you that people can still think like this after so many years of transformation. You actually are forced to work twice as } \\
\text { hard to prove to them that you are competent and capable of doing the job.' }\end{array}$ \\
\hline & Suspicious & $\begin{array}{l}\text { 'You experience them when you try to break the sense of working in silos trying to draw from each other's expertise and } \\
\text { knowledge, HR-related matters. You sort of sense it then to say "why does she want to work with us", "why is she interested", } \\
\text { so there is some level of suspiciousness, people are sort of guarded of their territories, they don't want people to come into } \\
\text { their space.' }\end{array}$ \\
\hline \multirow[t]{8}{*}{ Cognitive effect } & Challenging & $\begin{array}{l}\text { 'It can be very frustrating because from a career perspective where you think "I am capable of doing this and I can do it very } \\
\text { well" and if a lot of obstacles and hurdles are placed before you it means there are a lot of barriers to access, limiting access } \\
\text { to those opportunities and it can be frustrating.' }\end{array}$ \\
\hline & Cynicism & $\begin{array}{l}\text { 'They impact a lot because eventually you feel tied in the corner, you give information and they go back to verify with } \\
\text { somebody superior to you. It impacts negatively on one's career because you feel that you are not treated fairly, you are not } \\
\text { respected and then why should you still be in this environment.' }\end{array}$ \\
\hline & Discriminating; derogatory & $\begin{array}{l}\text { 'Discriminatory sometimes derogatory. It's like you forever have to prove yourself that you are indeed capable of doing a job. } \\
\text { So it's like you are constantly trying to prove a point and it shouldn't be like that I think.' }\end{array}$ \\
\hline & Doubt & $\begin{array}{l}\text { 'But sometimes if you doubt yourself your self-esteem might actually be affected and you might end up having an inferiority } \\
\text { complex.' }\end{array}$ \\
\hline & Exclusion & 'You feel like an outcast. This makes you feel like you are not part of the group. You feel isolated, lonely and excluded.' \\
\hline & Limiting & $\begin{array}{l}\text { 'Frustration and you feel limited. It affects your enthusiasm, your energy, your sense of innovation and working together and } \\
\text { learning from each other, so it's quite limiting.' }\end{array}$ \\
\hline & Negative & $\begin{array}{l}\text { 'We experience them in a negative way because people would generalise and say bad things about you because they did not } \\
\text { get the response that they expected from you.' }\end{array}$ \\
\hline & Embarrassing & $\begin{array}{l}\text { 'They come out very strong, trying to make a point but when other managers listen to them and realise this is not what they } \\
\text { want, that becomes like a work conflict. You feel so embarrassed and you also feel stupid as if you studied for nothing'. }\end{array}$ \\
\hline \multirow[t]{3}{*}{ Emotional effect } & Frustrating; agitating & $\begin{array}{l}\text { 'It impairs on the effectiveness of team work and team cohesiveness within the HR environment. You feel more frustrated and } \\
\text { agitated.' }\end{array}$ \\
\hline & Irritated & 'It irritates you that people can still think like this after so many years of transformation.' \\
\hline & Sad & $\begin{array}{l}\text { 'One of the stereotypes that we experience from } \mathrm{HR} \text { side ... is that when you work in } \mathrm{HR} \text {, you are not taken as a serious } \\
\text { member of the organisation especially the academics ... It irritates me. I feel so sad that they are so narrow-minded.' }\end{array}$ \\
\hline No effect & Not bothered & 'I think if people still have an opinion of what people say I think they need to wake up. I just laugh it off because it's not true.' \\
\hline
\end{tabular}

$(N=30)$

defensive, having to prove themselves or becoming suspicious. Cognitive effect: Many participants reported that they experience stereotypes to be challenging, discriminating, derogatory, limiting, negative, cynicism, doubting and excluding.

Emotional effect: The participants reported that they feel frustrated, agitated, irritated, sad and embarrassed when confronted with stereotypes.

The theme that included the most sub-themes was cognitive effect with eight sub-themes identified as: challenging, discriminating, derogatory, limiting, negative, cynicism, doubting and excluded.

The theme with the least number of sub-themes was behavioural effect. Most of the different effects mentioned by the participants were negative.

\section{Perceived stereotypes about others (Category 3)}

In this category, the participants were requested to give an account of stereotypes that they held of other people. Whilst it was evident that some participants did hold stereotypes of other people, a number of participants reported that they do not stereotype as they believe that they are open-minded, exposed to diverse groups and that they could form their own impressions.

Table 3 shows the broad themes on the perceived stereotypes about others, the sub-themes, the characteristics as well as examples of original responses that were analysed. The main perceived stereotypes about others included:

Age: Older employees perceive young employees to be conceited and technologically advanced. On the other hand, the young employees perceive the older employees to be all-knowing, begrudging and technologically challenged.

Culture: Zulu men are perceived to be polygamous whereas Sotho men are seen to be more assertive.

Gender: Men are stereotyped as being valuable. Black men are stereotyped to be patronising, ambitious and resistant to change.

Occupational: Human Resources employees are perceived to be superior. Academics are stereotyped to be conceited, troublesome, undermining, critical, rude and mean. Negotiators are seen to be rude. Managers are stereotyped to be narrow-minded, intimidating, incompetent and controlling.

Racial: White people are seen to be conceited, not knowledgeable about other races; however, they are also viewed as not being racist.

The theme that had the most number of sub-themes was occupational stereotypes whereas the culture theme had the least number of sub-themes. Most participants held negative stereotypes about different groupings within their 
TABLE 3: Perceived stereotypes about others.

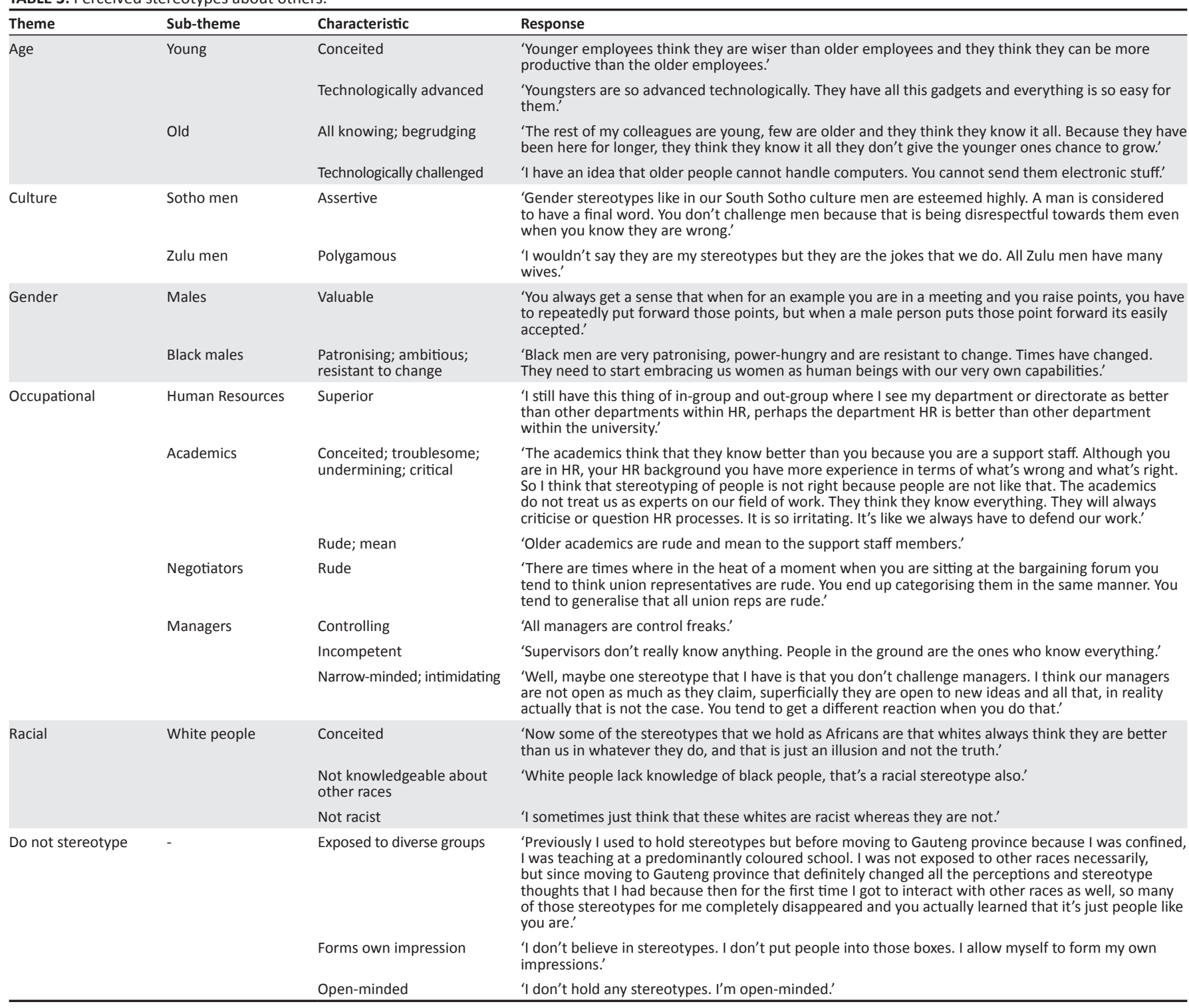

$(N=30)$

\section{workplace.}

\section{Discussion}

The aim of this study was to explore the experiences of stereotyping on individuals working within a higher education institution.

The first research objective was to determine the stereotypes that the participants associate with themselves in their workplace. The research findings give an indication that the participants associate themselves with the following stereotypes: age, gender, occupational and racial stereotypes. Women see themselves as having to overcompensate to prove themselves, be more assertive to pull rank and they feel they are disregarded as leaders, undervalued and taken advantage of. They also associate themselves with the stereotype that they are inefficient, incompetent and not intelligent. Literature supports this finding as men are often perceived to be better managers or leaders than women (Heilman, Wallen, Fuchs \& Tamkins, 2004; Still, 2006). Coward (2010) states that people are conditioned to expect women to be less competent; therefore, women have to prove to be overly competent to be taken seriously. Amble (2005) mentions that women leaders will always be undermined and misjudged, regardless of their talents or aptitudes. The results of this study indicate that the respondents hold more negative stereotypes about themselves. Schneider (2004) states that people seem to have stronger and more negative stereotypes about groups to which they do not belong than about those to which they do, which contradicts the findings of this study.

With regard to the age stereotype, the research findings give an indication that young people associate themselves with the perception that they are incompetent. Older people associate themselves with the stereotype that they are mature and professional but, on the other hand, inefficient. Rupp, Vodanovich and Crede (2006) state that managers with significant age-based bias cited older employees for poor performance more often and more severely than they cited younger employees. However, according to McGregor (2002) 
young workers also face prejudice based upon stereotypes. Prenda and Stahl (2001) mention that even though younger employees may be faster than older employees at certain computer-related tasks, they are not more accurate.

The results of this study indicate that, in terms of the occupational stereotypes, Human Resources personnel perceive themselves to be undermined. Human Resources specialists see themselves as conceited and knowledgeable. Support staff is believed to be not intelligent and managers are perceived to disregard subordinates. According to Fein and Spencer (1997) individuals negatively stereotype others in order to feel better about themselves, which may also explain the results of this study.

In terms of the racial stereotypes, black people believe themselves to be perceived as disrespectful, unreliable, not intelligent, not hardworking, not knowledgeable, criminals and incompetent. People of mixed race think they are viewed as being gangsters, drinking a lot and being wild and incompetent. Recent literature has also found that these stereotypes do exist about mixed race individuals (Adhikari, 2006; Talbot \& Durrheim, 2012). Indians associate themselves with the perception that they are crooks and materialistic. According to Blaine (2007), indians are associated with stereotypes that they are timid, sly, conforming and untrustworthy. White people feel they are viewed as being conceited, knowledgeable and racist. According to Schneider (2004), white people described themselves as competitive, lazy, intelligent, independent and arrogant, which confirms the study findings. It is evident that most of the stereotypes mentioned were negative. Blaine (2007) confirms this by stating that stereotypes of many social groups are predominantly composed of negatively valued qualities.

The second research objective was to determine how the participants experience stereotypes that they are confronted with. Literature indicates that when confronted with stereotypes, people react differently: stereotypes have different effects on different people. It has been shown that stereotyping with negative images often leads to negative outcomes such as performance decrement (Bargh, Chen \& Burrows 1996; Cadinu, Maass, Rosabianca \& Kiesner, 2005; Shih, Pittinsky \& Ambady 1999; Steele 1997). The results of the study also indicate that the experiences of stereotypes were mostly negative. Stereotypes can have cognitive, emotional and behavioural effects on the stereotyped group (Gordon, 2001). Such effects were also found in this study. A behavioural effect is a behaviour that occurs as a result of a person's feeling about a focal person, object or situation (Kreitner \& Kinicki, 2004). The results of this study indicate that most of the participants responded by either avoiding the person who holds the stereotype, becoming defensive, having to prove themselves and becoming suspicious when confronted with stereotypes. A cognitive effect occurs when individuals have beliefs about a certain person, object or situation that they accept as true based on their values and experiences (Gordon, 2001). Many participants reported that they experienced stereotypes to be challenging, discriminating, derogatory, limiting, negative and resulting in cynicism, doubt and exclusion. An emotional effect refers to the feelings that people have that result from their beliefs about a person, object or situation (Kreitner \& Kinicki, 2004). The participants reported that they feel frustrated, agitated, irritated, sad and embarrassed when confronted with stereotypes.

The third research objective was to determine what stereotypes the participants hold of other people within their workplace. It is clearly indicated by the data collected that the participants do hold negative stereotypes of other people within their workplace. According to Onwunta and August (2007), most of the stereotypes that one can think of are predominantly negative. The authors further mentioned that it was true that some stereotyping may be positive, but that most of the popular stereotypes are negative and one hardly hears any positive stereotyping, especially about women. However, according to Carpenter and Hewstone (1996), contact between members of different groups enables discovery of mutual similarities and thereby positively changes stereotypical attitudes towards each other. The common stereotypes that the participants in this study held were stereotypes in terms of age, culture, gender, occupation, qualifications and race.

The results of the present study indicate that older people perceive younger people to be conceited and technologically advanced, and young people perceive the older people to be all-knowing, begrudging and technologically challenged. Regarding the age stereotype, older workers view older people more favourably than they do younger people (Celejewski \& Dion, 1998; Spears, Doosje \& Ellemers, 1997). According to Hedge, Borman and Lammlein (2006) age stereotypes and age norms can have a significant influence on expectations of performance, performance itself and how that performance is evaluated. Results of this study also indicate that men are perceived to be valuable. Blaine (2007) agrees with this by stating that men are perceived as better, more competent and more valuable people than women (Blaine, 2007). In the present study, black men are perceived to be patronising, ambitious and resistant. Schneider (2004) stated that black people described white people to be prejudiced, corrupt, mean and selfish, which is somewhat in agreement with the results of this study, where white people are seen to be conceited and not knowledgeable about other races. In terms of the occupational stereotypes, Mandy, Milton and Mandy (2004) stated that stereotypical perceptions exist within certain professional groups. Each professional group views itself more positively than it views the other professions (Streed \& Stoecker, 1991); however, this was not the case in the present study. Mandy et al. (2004) further state that occupational stereotypes might emerge due to the increased lack of understanding of each other's professional role. In this study, Human Resources personnel were seen to be superior. Academics were perceived to be conceited, troublesome, undermining, critical, rude and mean. Managers were seen to be narrow-minded, intimidating, 
incompetent and controlling. People with low qualifications were seen to be inexperienced and incompetent.

\section{Practical implications}

Collins, Walker and Hamda (2011) state that organisations can do the following to become more aware of stereotypes that exist within the workplace:

- Challenge stereotypic comments and assumptions when they hear them.

- Suggest changes in systems and processes to make them more equitable and accessible.

- Spend time (e.g. meals, breaks) with people who are different from them in a variety of ways.

- Let people know that ethnic, gender, racial, religious and other jokes of that ilk are off limits.

- Suggest methods to hold all staff accountable for fair treatment and respectful behaviour.

- Speak up and educate when you hear a derogatory comment, slur or joke.

- Suggest resolution strategies when staff has diversityrelated conflicts.

- Challenge your own assumptions and stereotypic thoughts.

- Give suggestions about ways to make the department more inclusive.

- Check out the facts before passing on information.

For future research it is recommended that additional research designs such as multiple case studies, grounded theory or triangulation be considered to explore stereotypes. A bigger sample should also be used which includes support staff members from academic institutions from other provinces. It is also recommended that future research focus on including other occupational groups and not only focuses on support staff as they do not perform similar jobs.

\section{Limitations of the study}

There are some limitations to this study. The method used in the study, the case study design, is not generalisable because it focuses on only a few individuals. The sample size was small, consisting of 30 support staff members only. This could have been extended to the academic staff as well. Therefore, the results cannot be generalised for the whole institution. Also, data was collected within only one higher education institution in Gauteng and may, therefore, not be representative of all support staff within all higher education institutions in South Africa.

\section{Conclusion}

The findings of this study clearly indicate that stereotypes are indeed prevalent in a South African higher education institution. Findings show that participants associate themselves with stereotypes and also hold stereotypes of others. The types of stereotypes that are most prevalent are age, gender, occupational and racial stereotypes. Most of the stereotypes that were mentioned were negative in nature. It is also clear that stereotypes do have different effects on the persons being stereotyped, whether the effect is behavioural, cognitive or emotional. To conclude, stereotypes are indeed an important topic to study, considering the different types that are experienced within a diverse South Africa, and the potential negative effects they have on individuals and organisations.

\section{Acknowledgements Competing interests}

The authors declare that they have no financial or personal relationship(s) that may have inappropriately influenced them in writing this article.

\section{Authors' contributions}

G.R.B.M. (North-West University) collected the data, conducted the data analysis, conducted final integration of the data and wrote the introduction, literature review, research design, findings, discussion and conclusion. She sent the final draft for language editing and made corrections based on recommendations of the language editor. L.B. (North-West University) and J.A.N. (North-West University) reviewed the data analysis, provided feedback on the final integration of data and provided feedback on the final copy of the manuscript.

\section{References}

Adhikari, M. (2006). 'God made the white man, God made the black man...': Popular racial stereotyping of coloured people in apartheid South Africa. South African Historical Journal, 55, 142-164. http://dx.doi.org/10.1080/02582470609464935

Amble, B. (2005). Gender stereotypes block women's advancement. Management Issues. Retrieved October 12, 2012, from http://www.management-issues. com/2006/8/24/research/gender-stereotypes-block-womens-advancement.asp

Arkkelin , D., \& O'Connor, R. Jr. (1992). The good professional: Effects of trait-profile gender type, androgyny, and likeables on impressions of incumbents of sex-typed occupation. Sex Roles, 26, 517-532. http://dx.doi.org/10.1007/BF00290007

Bargh, J.A., Chen, M., \& Burrows, L. (1996). Automaticity of social behavior: Direct effects of trait construct and stereotype activation on action. Journal of Personality and Social Psychology, 71, 230-244. http://dx.doi.org/10.1037/0022 3514.71.2.230

Basow, S.A. (1992). Gender stereotypes and roles. (3rd edn.). Pacific Grove, CA Brooks/Cole Publishing Company.

Ben-Zeev, T., Fein, S., \& Inzlicht, M. (2005). Arousal and stereotype threat. Journal of Experimental Social Psychology, 41, 174-181. http://dx.doi.org/10.1016/j. jesp.2003.11.007

Blaine, B.E. (2007). Understanding the psychology of diversity. Thousand Oaks, CA: Sage

Blascovich, J., Spencer, S.J., Quinn, D.M., \& Steele, C.M. (2001). African-Americans and high blood pressure: The role of stereotype threat. Psychological Science, 12 225-229. http://dx.doi.org/10.1111/1467-9280.00340

Bless, C., Higson-Smith, C., \& Kagee, A. (2006). Fundamentals of social research methods: An African perspective. (4th edn.). Cape Town, South Africa: Juta \& Company Ltd.

Bowen, W.G., Kurzweil, M.A., \& Tobin, E.M. (2005). Equity and excellence in American higher education. Charlottesville, VA: University of Virginia Press.

Branscombe, N.R., Schmitt, M.T., \& Harvey, R.D. (1999). Perceiving pervasive discrimination amongst African Americans: Implications for group identification and wellbeing. Journal of Personality and Social Psychology, 77, 135-149. http:// dx.doi.org/10.1037/0022-3514.77.1.135

Brotherton, C. (2007). The social psychology of prejudice, stereotyping and discrimination. Journal of Community and Applied Social Psychology, 17, 159-167. http://dx.doi.org/10.1002/casp.890

Buelens, M., Sinding, K., Waldstrøm, C., Kreiter, R., \& Kinicki, A. (2011). Organisationa behaviour. (4th edn.). New York, NY: McGraw-Hill.

Burgess, H. (2003). Stereotypes/characterization frames: Beyond intractability. Boulder, CL: Conflict Information Consortium, University of Colorado. Retrieved September 20, 2012, from http://www.beyondintractability.org/essay/ stereotypes/

Cadinu, M., Maass, A., Rosabianca, A., \& Kiesner, J. (2005). Why do women underperform under stereotype threat? Evidence for the role of negative 
thinking. Psychological Science, 16(7), 572-578. http://dx.doi.org/10.1111/ j.0956-7976.2005.01577.x

Carpenter J., \& Hewstone M. (1996). Shared learning for doctors and social workers. British Journal of Social Work, 26, 239-257. http://dx.doi.org/10.1093/ oxfordjournals bjsw.a011082

Celejewski, I., \& Dion, K.K. (1998). Self-perception and perception of age groups as a function of the perceiver's category membership. International Journal of Aging \& Human Development, 47, 205-216. http://dx.doi.org/10.2190/GL4R-FJ7G-XGEKMRR6

Clark, R., Anderson, N.B., Clark, V.R., \& Williams, D.R. (1999). Racism as a stressor for African Americans: A biopsychosocial model. American Psychologist, 54, 805-816. http://dx.doi.org/10.1037/0003-066X.54.10.805

Collins, G., Walker, M., \& Hamda, G. (2011). Preaching to the choir on cultivating diversity in the workplace. Retrieved October 12, 2012, from www.icatt.net

Coward, L.S. (2010). Barriers to women's progress: Psychology as basis and solution. Forum on Public Policy. Retrieved October 13, 2012, from http:// forumonpublicpolicy.com/Vol2010no5/archivevol2010no5/coward.pdf

De Klerk, V., \& Radloff, S. (2010). Measuring the effect of diversity interventions at a South African residential university. The International Journal of Diversity in Organisations, Communities and Nations, 10(2), 25-46.

Dovidio, J.F., Glick, P., \& Rudman L.A. (Eds.). (2005). On the nature of prejudice Fifty years after Allport. Oxford, UK: Blackwell Publishers. http://dx.doi. org/10.1002/9780470773963

Durrheim, K., \& Wassenaar, D. (2002). Putting design into practice: Writing and evaluating research proposals. In M. Terre Blanche, \& K. Durrheim (Eds.) Research in practice: Applied methods for the social sciences (pp. 54-71). Cape Town, South Africa: Cape Town University Press.

Eagly, A.H., \& Karau, S.J. (2002). Role congruity theory of prejudice towards female leaders. Psychological Review, 10(3), 573-598. http://dx.doi.org/10.1037/0033295X.109.3.573

Falkenberg, L. (1990). Improving the accuracy of stereotypes within the workplace. Journal of Management, 16(1), 107-118. http://dx.doi. org/10.1177/014920639001600108

Fein, S., \& Spencer, S.J. (1997). Prejudice as self-image maintenance: Affirming the self through derogating others. Journal of Personality and Social Psychology, 73 31-44. http://dx.doi.org/10.1037/0022-3514.73.1.31

Fiske, S.T., \& Stevens, L.E. (1993). What's so special about sex? Gender stereotyping and discrimination. In S. Oskamp, \& M. Costanzo (Eds.), Gender issues in contemporary society: Applied social psychology annual, Vol. 6, (pp.173-196). Newbury Park, CA: Sage Publications.

Fiske, S.T., \& Taylor, S.E. (1991). Social cognition. (2nd edn.). New York, NY: McGraw Hill.

Gibbons, F.X., Gerrard, M., Cleveland, M.J., Wills, T.A., \& Brody, G. (2004). Perceived discrimination and substance use in the American parents and their children: A panel study. Journal of Personality and Social Psychology, 86, 517-529. http:// panel study. Journal of Personality and
dx.doi.org/10.1037/0022-3514.86.4.517

Gill, G. (2012, January). Avoiding stereotypes in the workplace. HRVoice.org Retrieved July 24, 2012, from http://www.hrvoice.org/avoiding-stereotypes-inthe-workplace/

Gordijn, E., Finchilescu, G., Brix, L., Wijnants, N., \& Koomen, W. (2006). The influence of prejudice and stereotypes on anticipated affect: Feelings about a potentially negative interaction with another ethnic group. South African Journal of Psychology, 38(4), 589-601. http://dx.doi.org/10.1177/008124630803800401

Gordon, J.R. (2001). Organizational behaviour: A diagnostic approach. (7th edn.) Boston, MA: Prentice Hall.

Guba, E.G. (1981). Criteria for assessing the trustworthiness of naturalistic inquiries. Educational Resources Information Centre Annual Review Paper, 29, 75-91.

Hedge, J.W., Borman, W.C., \& Lammlein, S.E. (2006). The aging workforce: Realities, myths, and implications for organizations. Washington, DC: American Psychological Association. http://dx.doi.org/10.1037/11325-000

Heilman, M.E., Wallen, A.S., Fuchs, D., \& Tamkins, M.M. (2004). Penalties for success: Reactions to women who succeed at male gender-typed tasks. Journal of Applied Psychology, 89, 416-427. http://dx.doi.org/10.1037/0021-9010.89.3.416

Hinton, P.R. (2000). Stereotypes, cognition and culture. East Sussex, PA: Psychology Press.

Kassin, S., Fein, S., \& Markus, H.R (2011). Social psychology. (8th edn.). Wadsworth, $\mathrm{OH}$ : Cengage Learning.

Kerlinger, F.N. (2000). Foundations of behavioral research. (4th edn.). New York, NY Holt, Rinehart \& Winston.

Krefting, L. (1991). Rigor in qualitative research: The assessment of trustworthiness The American Journal of Occupational Therapy, 45(3), 214-222. http://dx.doi. org/10.5014/ajot.45.3.214

Kreitner, R., \& Kinicki, A. (2004). Organizational behavior. (6th edn.). New York, NY: McGraw-Hill/Irwin.

Larkin, J.D. (2008). Stereotypes and decision making: Reconciling discrimination law with science. CPER Journal, 192, 15-24.

Lester, S. (1999). An introduction to phenomenological research. Taunton, UK: Stan Lester Developments.

Lincoln, Y.S., \& Guba, E.A. (1985). Naturalistic inquiry. London, UK: Sage Publications.

Lipton, J.P., O'Connor, M., Terry, C., \& Bellamy, E. (1991). Neutral job titles and occupational stereotypes: When legal and psychological realities conflict. Journa of Psychology, 125(2), 129-151. http://dx.doi.org/10.1080/00223980.1991.1054
3278

MacNealy, M.S. (1999). Strategies for empirical research in writing. New York, NY: Longman.

Madden., M. (2011). Four gender stereotypes of leaders: Do they influence leadership in higher education? Wagadu, 9, 55-89.

Mandy, A., Milton, C., \& Mandy, P. (2004). Professional stereotyping and interprofessional education. Learning in Health and Social Care, 3(3), 154-170. http://dx.doi.org/10.1111/j.1473-6861.2004.00072.x

Mayekiso, T., \& Snodgrass, L. (2008). Managing diversity in transforming institutions of higher education: The case of Nelson Mandela Metropolitan University, South Africa. The International Journal of Diversity in Organisations, Communities and Nations, 8(5), 123-129.

McGregor, J. (2002). Stereotypes and older workers. Journal of Social Policy, 18 163-177.

McKinney, G. (1996, November). Stereotypes and cultural diversity in the workplace. Retrieved September 13, 2012, from http://cobweb2.louisville.edu/faculty/ regbruce/bruce//rflct600/genita2.htm

McLean, H.M., \& Kalin, R. (1994). Congruence between self-image and occupational stereotypes in students entering gender-dominated occupations. Canadian Journal of Behavioural Science, 26(1), 142-162. http://dx.doi.org/10.1037/0008400X.26.1.142

Mendes, W.B., Major, B., McCoy, S., \& Blaschovich, J. (2008). How attributional ambiguity shapes physiological and emotional responses to social rejection and acceptance. Journal of Personality and Social Psychology, 94, 278-291. http:// dx.doi.org/10.1037/0022-3514.94.2.278

Moore, J. R. (2006). Shattering stereotypes: A lesson plan for improving student attitudes and behaviour toward minority groups. Social Studies, 97(1), 35-39. http://dx.doi.org/10.3200/TSSS.97.1.35-39

Niemann, R. (2006). Managing workforce diversity in South African schools. South African Journal of Education, 26(1), 97-112.

Norris, B.D. (1996). Managing diversity within South African technikons: A strategic management approach. South African Journal of Higher Education, 10, 25-27.

O'Brien, L.T., \& Crandall, C.S. (2003). Stereotype threat and arousal: Effects on women's math performance. Personality and Social Psychology Bulletin, 29, 782789. http://dx.doi.org/10.1177/0146167203029006010

Onwunta, I.E., \& August, T.H. (2007). Stereotyping in communities: A story of the endangered gender in Nigeria. Practical Theology in South Africa, 22(2), 139-15.

Oswald, P.A. (2003). Sex-typing and prestige ratings of occupations as indices of occupational stereotypes. Perceptual and Motor Skills, 97, 953-959. http:// dx.doi.org/10.2466/pms.2003.97.3.953

Pauker, K., Ambady, N., \& Apfelbaum, E.P. (2010). Race salience and essentialist thinking in racial stereotype development. Child Development, 81(6), 1799-1813. http://dx.doi.org/10.1111/j.1467-8624.2010.01511.x

Plous, S. (2003). The psychology of prejudice, stereotyping, and discrimination: An overview. In S. Plous (Ed.), Understanding prejudice and discrimination (pp. 3-48). New York, NY: McGraw-Hill.

Powell, G.N., \& Butterfield, D.A. (2002). Exploring the influence of decision makers' ethnicity and gender on actual promotions to top management. Personne Psychology, 55, 397-419. http://dx.doi.org/10.1111/j.1744-6570.2002.tb00115.x

Prenda, K.M., \& Stahl, S.M. (2001). The truth about older workers. Business and Health, 19, 30-35.

Prime, J., Jonsen, K., Carter, N., \& Maznevski, M.L. (2008). Managers' perceptions of women and men leaders: A cross cultural comparison. Internationa Journal of Cross Cultural Management, 8, 171-210. http://dx.doi. org/10.1177/1470595808091789

Rake, C., \& Lewis, R. (2009). Just below the surface: Gender stereotyping, the silent barrier to equality in the modern workplace? The Fawcett Society. Retrieved July 24, 2012, from http://www.fawcettsociety.org.uk/documents/just below the Surface.pdf

Roberson, L., \& Kulik, C.T. (2007). Stereotype threat at work. Academy of Management Perspectives, 24-40. http://dx.doi.org/10.5465/AMP.2007.25356510

Robinson, T., Gustafson, B., \& Popovich, M. (2008). Perceptions of negative stereotypes of older people in magazine advertisements: Comparing the perceptions of older
adults and college students. Ageing and Society, 28, 233-251. http://dx.doi. adults and college students. Ageing
org/10.1017/S0144686X07006605

Rupp, D.E., Vodanovich., S.J., \& Crede., M. (2006). Age bias in the workplace: The impact of ageism and causal attributions. Journal of Applied Social Psychology, 36, impact of ageism and causal attributions. Journal of Applied Social

Salkind, N.J. (2009). Exploring research. (7th edn.). Upper Saddle River, NJ: Prentice Hall.

Sanderson, C.A. (2010). Social psychology. New York, NY: John Wiley \& Sons.

Sargeant, M. (Ed.). (2011). Age discrimination and diversity: Multiple discrimination from an age perspective. New York, NY: Cambridge University Press. http://dx.doi org/10.1017/CBO9780511777196

Schmader, T., \& Johns, M. (2003). Converging evidence that stereotype threat reduces working memory capacity. Journal of Personality and Social Psychology, 85, 440452. http://dx.doi.org/10.1037/0022-3514.85.3.440

Schmader, T., Johns, M., \& Forbes, C. (2008). An integrated process model of stereotype threat effects on performance. Psychological Review, 115, 336-356. http://dx.doi.org/10.1037/0033-295X.115.2.336

Schmitt, M. T., \& Branscombe, N.R. (2002). The internal and external causal loci of attributions to prejudice. Personality and Social Psychology Bulletin, 28, 620-628. 
http://dx.doi.org/10.1177/0146167202288006

Schneider, D.J. (2004). The psychology of stereotyping. London, UK: Guilford Press.

Schurink, W., Fouche, C.B., \& De Vos, A.S. (2011). Qualitative data analysis and interpretation. In A.S. De Vos, H. Strydom, C.B. Fouche, \& C.S.L. Delport (Eds.), Research at grass roots: For the social sciences and human service professions (4th edn. pp. 397-423). Pretoria, South Africa: Van Schaik Publishers.

Shih, M., Pittinsky, T.L., \& Ambady, N. (1999). Stereotype susceptibility: Identity salience and shifts in quantitative performance. Psychological Science, 10, 80-83. http://dx.doi.org/10.1111/1467-9280.0011

Singletary, S.L., Ruggs, E.N., Hebl, M.R., \& Davies, P.G. (2009). Literature overview: Stereotype threat: Causes, effects, and remedies. Retrieved September 13, 2012, from http://www.engr.psu.edu/awe/misc/ARPs/ARP_StereotypeThreat 2012, from http://wi
Overview 31909.pdf

Solovic, S.W. (2010, May). Workplace stereotyping: A silent productivity destroyer. The Huffington Post. Retrieved October 12, 2012, from http://www.huffingtonpost. com/susan-wilson-solovic/workplace-stereotyping-a_b_564233.html

Spears, R., Doosje, B., \& Ellemers, N. (1997). Self-stereotyping in the face of threats to group status and distinctiveness: The role of group identification. Personality and Social Psychology Bulletin, 23, 528-553. http://dx.doi. org/10.1177/0146167297235009

Spencer, S.J., Steele, C.M., \& Quinn, D. (1999). Stereotype threat and women's math performance. Journal of Experimental Social Psychology, 35(1), 4-28. http:// dx.doi.org/10.1006/jesp.1998.1373

Steele, C.M. (1997). A threat in the air: How stereotypes shape intellectual identity and performance. American Psychologist, 52, 613-629. http://dx.doi. org/10.1037/0003-066X.52.6.613

Steele, C.M., \& Aronson, J. (1995). Stereotype threat and the intellectual test performance of African-Americans. Journal of Personality and Social Psychology, 69, 797-811. http://dx.doi.org/10.1037/0022-3514.69.5.797

Still, L.V. (2006). Gender, leadership and communication. In M. Barrett \& M.J. Davidson (Eds.), Gender and communication at work (pp. 183-210). Aldershot, UK: Ashgate.

Streed C.P., \& Stoecker J.L. (1991). Stereotyping between physical therapy students and occupational therapy students. Physical Therapy, 71, 16-24.

Streubert, H., \& Carpenter, D. (1999). Qualitative research in nursing: Advancing the humanistic perspective. (2nd edn.). Philadelphia, PA: Lippincott Williams \& Wilkins.

Talbot, K., \& Durrheim, K. (2012). The Princeton trilogy revisited: How have racia stereotypes changed in South Africa? South African Journal of Psychology, 42(4), 476-491.

Terre Blanche, M., \& Durrheim, K. (1999). Research in practice: Applied methods for the social sciences. Cape Town, South Africa: University of Cape Town Press.

Thomas, K.S., Bardwell, W.A., Ancoli-tsrael, S., \& Dimsdale, J.E. (2006). The toll of ethnic discrimination on sleep architecture and fatigue. Health Psychology, 25 635-642. http://dx.doi.org/10.1037/0278-6133.25.5.635 